\title{
The Relationship Between Morning Symptoms and the Risk of Future Exacerbations in COPD [Corrigendum]
}

Sun T, Li X, Cheng W, et al. Int J Chron Obstruct Pulmon

Dis. 2020;15:1899-1907.
The authors have advised that there are errors in Table 3 on page 1905 . The correct table is shown below.

Table 3 The Relationship Between Morning Symptoms and the Exacerbations of the One-Year Follow-Up Period

\begin{tabular}{|c|c|c|c|c|}
\hline & All Patients $(\mathbf{N}=\mathbf{7 8})$ & $\begin{array}{l}\text { Morning Symptoms } \\
\text { Score }<30.0(N=39)\end{array}$ & $\begin{array}{l}\text { Morning Symptoms } \\
\text { Score } \geq 30.0(N=39)\end{array}$ & P-value \\
\hline \multicolumn{5}{|l|}{ Exacerbations during follow-up, $\mathrm{n}(\%)$} \\
\hline No exacerbation & $46(59.0)$ & $27(69.2)$ & 19 (48.7) & 0.066 \\
\hline Moderate exacerbations & $22(28.2)$ & II (28.2) & II (28.2) & 1.000 \\
\hline Severe exacerbations & $17(21.8)$ & $3(7.7)$ & $14(35.9)$ & 0.003 \\
\hline Frequent exacerbations & $17(21.8)$ & $6(15.4)$ & II (28.2) & 0.170 \\
\hline \multicolumn{5}{|l|}{ Exacerbations during follow-up, median [IQR] } \\
\hline Total exacerbations & $0(0,1)$ & $0(0,1)$ & I $(0,2)$ & 0.078 \\
\hline Moderate exacerbations & $0(0, I)$ & $0(0,1)$ & $0(0,1)$ & 0.950 \\
\hline Severe exacerbations & $0(0,0)$ & $0(0,0)$ & $0(0,1)$ & 0.002 \\
\hline
\end{tabular}

Notes: Data are presented as the median (IQR), or number (\%). Data were compared between two groups using Mann-Whitney $U$-test, and $2 \chi$ test. Abbreviations: SD, standard deviation; IQR, interquartile range.

\section{Publish your work in this journal}

The International Journal of COPD is an international, peer-reviewed journal of therapeutics and pharmacology focusing on concise rapid reporting of clinical studies and reviews in COPD. Special focus is given to the pathophysiological processes underlying the disease, intervention programs, patient focused education, and self management protocols. This journal is indexed on PubMed Central, MedLine and CAS. The manuscript management system is completely online and includes a very quick and fair peer-review system, which is all easy to use. Visit http://www.dovepress.com/testimonials.php to read real quotes from published authors. 